\title{
Isolation and Characterization of Newcastle Disease Virus Subgenotype VII.2/VIIi from Commercial Chicken and Swan in Malaysia
}

\author{
Siti Nor Azizah Mahamud ${ }^{1}$, Sheau Wei Tan ${ }^{1}$, So-Youn Youn ${ }^{2}$, Hyun-Jeong Lee ${ }^{3}$, \\ Ji-Youn Lee ${ }^{2}$, Young-Kuk Kwon ${ }^{2}$, Aini Ideris ${ }^{1,4}$ and Abdul Rahman Omar ${ }^{1,4 *}$ \\ ${ }^{1}$ Institute of Bioscience, Universiti Putra Malaysia, 43400, Serdang, Selangor, Malaysia \\ ${ }^{2}$ Avian Disease Research Division, Animal and Plant Quarantine Agency, Gimcheon, Gyeongbuk 39660, \\ Republic of Korea \\ ${ }^{3}$ Center for Laboratory Control of Infectious Diseases, Center for Disease Control and Prevention, Osong, \\ Korea \\ ${ }^{4}$ Faculty of Veterinary Medicine, Universiti Putra Malaysia, 43400, Serdang, Selangor, Malaysia
}

\section{ABSTRACT}

Frequent Newcastle disease (ND) outbreaks in poultry have been reported in Southeast Asia, including Malaysia. However, limited studies have been carried out on detecting the Newcastle disease virus (NDV) from non-poultry birds. In this study, the detections of NDV were carried out using tissues samples from suspected ND cases from commercial chickens and swab samples of non-poultry birds captured in bird sanctuaries. Five samples from commercial chickens and one sample from black swans were found positive for ND. They were classified as velogenic NDV based on the partial sequencing of the fusion (F) gene, which revealed the amino acid motif on the F cleavage site of ${ }^{112} \mathrm{RRQKRF}{ }^{117}$. In addition, phylogenetic analysis based on partial $\mathrm{F}$ gene showed that all NVD isolates

ARTICLE INFO

Article history:

Received: 28 July 2021

Accepted: 30 September 2021

Published: 3 November 2021

DOI: https://doi.org/10.47836/pjtas.44.4.10

\section{E-mail addresses:}

snazizahmahamud@gmail.com (Siti Nor Azizah Mahamud) tansheauwei@gmail.com (Sheau Wei Tan)

syyoun@korea.kr (So-Youn Youn)

hyunjlee@korea.kr (Hyun-Jeong Lee)

enteric@korea.kr (Ji-Youn Lee)

kwonyk66@korea.kr (Young-Kuk Kwon)

aiini@upm.edu.my (Aini Ideris)

aro@upm.edu.my (Abdul Rahman Omar)

*Corresponding author are classified as class II genotype VII subgenotype VII.2 (VIIi) and are clustered together with NDVs isolated from chickens in 2017 in Indonesia. This finding indicates the occurrence of subgenotype VII.2 (VIIi) as the fifth panzootic of ND in Malaysia and the importance of the epidemiology of virulent NDV in various avian species.

Keywords: F gene cleavage site, genotype VII, subgenotype VII.2/VIIi

(C) Universiti Putra Malaysia Press 
Siti Nor Azizah Mahamud, Sheau Wei Tan, So-Youn Youn, Hyun-Jeong Lee, Ji- Youn Lee, Young-Kuk Kwon, Aini Ideris and Abdul Rahman Omar

\section{INTRODUCTION}

Newcastle disease (ND), particularly caused by the virulent Newcastle disease virus (NDV), is one of the most highly contagious diseases and causes high morbidity and mortality rates in infected chicken flocks worldwide. Hence, the disease is classified under list A poultry contagious disease by the Office International des Epizooties (World Organisation for Animal Health [OIE], 2012). Newcastle disease virus (NDV), previously known as Avian paramyxovirus type-1 (APMV1), has recently been classified as Avian orthoavulavirus 1 (AOaV-1), under the genus of Orthoavulavirus, subfamily Avulavirinae, and family Paramyxoviridae (International committee on taxonomy of viruses [ICTV], 2019). Even though NDV has a single serotype, due to its genetic diversity, the virus is further classified into several genotypes and subgenotypes based on the nucleotide sequences of the $\mathrm{F}$ protein cleavage site and phylogenetic analysis (Dimitrov et al., 2019).

Recently, Dimitrov et al. (2019) updated the virus's classification and nomenclature by adding three new genotypes, reducing some subgenotypes, and maintaining the two existing classes and existing genotypes. The new classification has changed the genotype VII landscape, as the subgenotypes were consolidated into three subgenotypes, namely subgenotype VII.1.1, which consists of VIIb, VIId, VIIe, VIIj, and VIIl; subgenotype VII.1.2 which consists of VIIf and subgenotype VII.2, which consists of VIIh, VIIi, and VIIk.
Five global panzootic outbreaks of ND have been reported. Genotypes II, III, and IV NDVs caused the first panzootic, from the 1920s to the 1960s (Alexander, 2009). The second panzootic outbreak was caused by genotype V NDV and occurred in the late 1960s in Europe (Lomniczi et al., 1998), while subgenotype VIb caused the third in the 1980s (Kaleta et al., 1985). Genotype VII caused the fourth panzootic outbreak in Southeast Asia in 1985 and then spread through Asia, Africa, Europe, and South America (Herczeg et al., 1999). A fifth panzootic is currently caused by genotype VII and primarily by subgenotypes VII.2 (VIIh and VIIi). It has spread rapidly across Asia and the Middle East (Diel et al., 2012; Miller et al., 2015).

Since ND was first reported in Java Island, Indonesia (Kraneveld, 1926), then in Newcastle-upon-Tyne, England in 1926 (Xiao et al., 2012), outbreaks have been continuously reported in many countries. In Malaysia, the first ND outbreak was reported in Parit Buntar, Perak, in poultry flocks in 1934. Since then, ND cases associated with different virulent and avirulent NDV strains have been reported, primarily in commercial poultry birds (Aljumaili et al., 2017; Berhanu et al., 2010; Jaganathan et al., 2015; Roohani et al., 2015; Satharasinghe et al., 2016; Shohaimi et al., 2015; Tan et al., 2009, 2010). However, there is limited information on the detection of NDV in nonpoultry birds and the transmission of NDV from non-poultry to commercial poultry birds in Malaysia. 
Previous studies have detected virulent NDV of various genotypes, especially genotype VII in dead or alive, healthy, or clinically ill, free-living or captive nonpoultry and wild birds displaying virulent properties with the presence of multiple basic amino acids at positions 112 to 116 and a phenylalanine residue at position $117\left({ }^{112} \mathrm{RRQKRF}^{117}\right.$ and $\left.{ }^{112} \mathrm{RRRKRF}^{117}\right)$. Among the bird species shown to be positive for NDVs are anseriformes (geese, wild mallards, white storks, egrets, black swans), galliformes (chickens, peacocks, pheasants, turkeys), psittaciformes (cockatoos, parrots), columbiformes (feral rock pigeon, Eurasian collared dove), falconiformes (Eurasian sparrowhawk, buzzards), and strigiformes (owls) (Miller et al., 2015; Turan et al., 2020; Vidanović et al., 2011; Wajid et al., 2017; Xie et al., 2012). Therefore, this study was conducted to determine the presence of NDV in non-poultry in bird sanctuaries and commercial chickens based on molecular characterization and thus to determine the current NDV strains circulating in the fields.

\section{METHODOLOGY}

\section{Swab Samples from Non-Poultry Birds}

Oropharyngeal and cloacal swab samples from non-poultry birds were collected in October 2017 from three different wild bird sanctuaries: Pusat Janaelektrik Sultan Salahuddin Aziz Shah, in Kapar, Selangor located in the central region of Peninsular Malaysia (3.116406, 101.324743); Pusat Konservasi Hidupan Liar Kuala Gula, in Perak, located in the northern region of Peninsular Malaysia (4.938800,
100.467408) and Putrajaya Wetland (2.962004, 101.695584). The sampling times and locations have coincided with flyways for the seasonal journey of the migratory birds from their breeding areas to Malaysia. These sampling programs were conducted together with a surveillance team from Jabatan Perlindungan Hidupan Liar dan Taman Negara Semenanjung Malaysia (PERHILITAN) Selangor and Perak under the permission certificate JPHL\&TN:100-6/1/14 (25). A total of 15 bird species $(n=75)$, including local wild birds, resident birds, and migratory birds, were caught, swabbed, and released back to nature. A total of 150 swabs were collected (75 oropharyngeal and 75 cloacal). According to species, these swabs were then pooled in $1 \mathrm{~mL}$ sterile phosphate buffer saline (PBS) (1st Base, Singapore); the 15 bird species were represented by five oropharyngeal and five cloacal swabs each. The birds were handled with proper personal protective equipment (PPE), and samples were taken under sterile conditions under 2012 OIE guidelines.

\section{Tissue Samples from Commercial Chickens}

Various tissue samples from commercial chickens suspected of having ND that was submitted to the Laboratory of Vaccines and Biomolecules, Institute of Bioscience (IBS), Universiti Putra Malaysia (UPM) for NDV detection using reverse transcriptasepolymerase chain reaction (RT-PCR) from 2016 to 2017 was used in this study. A total of 20 tissue samples were received from 
Siti Nor Azizah Mahamud, Sheau Wei Tan, So-Youn Youn, Hyun-Jeong Lee, Ji- Youn Lee, Young-Kuk Kwon, Aini Ideris and Abdul Rahman Omar

different poultry farms in several states around Malaysia. Each of the samples contained organs such as brains, tracheas, proventriculi, and cecal tonsils from five individual chickens.

\section{Molecular Characterization}

Virus Isolation and Propagation. Virus isolation and propagation were performed from tissue samples of commercial chickens tested positive for NDV by RT-PCR. Briefly, $30 \mathrm{mg}$ of the tissue were homogenized in a $50 \mathrm{~mL}$ centrifuge tube (SPL Life Sciences Co. Ltd., Korea) containing $3 \mathrm{~mL}$ sterile PBS using tissue rupture (QIAGEN, Germany) to produce homogenates. Then, the homogenates were centrifuged at 2,500 $\mathrm{x} g$ for $5 \mathrm{~min}$ at $10{ }^{\circ} \mathrm{C}$ (Eppendorf 5417R, Eppendorf, Germany). Next, the supernatant was aspirated and filtered using a 0.45 $\mu \mathrm{m}$ syringe filter (Sartorius, Germany) to produce inoculum. In the case of the swab samples of non-poultry birds, the inoculums were prepared by combining the oropharyngeal and cloacal swab samples and vortexed for $30 \mathrm{sec}$. Then, the samples were centrifuged at 2,500 $\mathrm{x}$ for $10 \mathrm{~min}$ at $10{ }^{\circ} \mathrm{C}$ and filtered using a $0.45 \mu \mathrm{m}$ syringe filter to produce inoculum.

Next, each inoculum was inoculated into five 10-day-old specific-pathogenicfree embryonated chicken eggs (SPF ECE) at a $0.1 \mathrm{~mL} /$ eggs volume, according to OIE (2012). The eggs were incubated at 37 ${ }^{\circ} \mathrm{C}$ (ESCO, Singapore) for five days. The allantoic fluids from the first inoculation were then harvested and used as inoculum for the second passage. Following completion of three serial passages in 10-day-old SPF ECE, the allantoic fluids were harvested and tested for hemagglutination activity via haemagglutination (HA) spot test according to OIE (2012).

RNA Extraction. According to the manufacturer's protocol, the allantoic fluids were extracted using TRIzol ${ }^{\circledR}$ reagent (Invitrogen, USA). Briefly, $300 \mu \mathrm{L}$ of the allantoic fluids were mixed with $750 \mu \mathrm{L}$ of TRIzol ${ }^{\circledR}$ reagent, then vortexed and incubated for $5 \mathrm{~min}$ at room temperature. Then, 200 $\mu \mathrm{L}$ of chloroform (Merck, Germany) was added, vortexed, and incubated for $10 \mathrm{~min}$ at room temperature. Next, the samples were centrifuged at $11,200 \times g$ and $10{ }^{\circ} \mathrm{C}$ for $10 \mathrm{~min}$. Subsequently, $500 \mu \mathrm{L}$ of the clear supernatant was mixed with $800 \mu \mathrm{L}$ of isopropanol (1st Base, Singapore) then vortexed and incubated on ice for $20 \mathrm{~min}$. Next, the mixture was centrifuged at 15,000 $\mathrm{x} g, 4^{\circ} \mathrm{C}$ for $15 \mathrm{~min}$, and the supernatant was discarded. The RNA was then washed with $800 \mu \mathrm{L}$ of $70 \%$ molecular grade ethanol (Merck, Germany) then washed again with $800 \mu \mathrm{L}$ of $100 \%$ molecular grade ethanol (Merck, Germany). Finally, the RNA pellet was air-dried for $10 \mathrm{~min}$ then reconstituted into $30 \mu \mathrm{L}$ of RNAse-free water (Qiagen, the Netherlands).

Primer Design. The primer set used in this study was designed by Berhanu et al. (2010), targeting the nucleotides sequence of the $\mathrm{F}$ gene at region 47 581, including the F0 cleavage site. This amplification was performed using forward 
primer, 5'-ATGGGC(C/T)CCAGA(C/T) CTTCTAC-3', and reverse primer, 5' - CTGCCACTGCTAGTTGTGA TAATCC -3 , with an expected size of $535 \mathrm{bp}$.

Reverse Transcriptase-Polymerase Chain Reaction (RT-PCR). A standard one-step RT-PCR was performed using a One-Step RT-PCR Kit (Biotechrabbit ${ }^{\mathrm{TM}}$, Germany). Briefly, $12 \mu \mathrm{L}$ of One-Step Mix, 2× was mixed with $1 \mu \mathrm{L}$ of RNAse-free water, $1 \mu \mathrm{L}$ of RT-RI Blend $20 \times, 1 \mu \mathrm{L}$ of forward primer $(20 \mu \mathrm{M}), 1 \mu \mathrm{L}$ of reverse primer $(20$ $\mu \mathrm{M}$ ), and finally $4 \mu \mathrm{L}$ of RNA template. Non-template control (NTC) was used as the negative control and NDV LaSota virus as the positive control. The PCR mixture was amplified in a thermocycler (C1000 Touch ${ }^{\mathrm{TM}}$ Thermal Cycler, Bio-Rad Laboratories, USA) set for $10 \mathrm{~min}$ at $48{ }^{\circ} \mathrm{C}$ for reverse transcription, $3 \mathrm{~min}$ at $95{ }^{\circ} \mathrm{C}$ for polymerase activation, 40 cycles of $20 \mathrm{sec}$ at $95^{\circ} \mathrm{C}$ for denaturation, $30 \mathrm{sec}$ at $58^{\circ} \mathrm{C}$ for annealing, $20 \mathrm{sec}$ at $72^{\circ} \mathrm{C}$ for extension, and $5 \mathrm{~min}$ at $72{ }^{\circ} \mathrm{C}$ for a final extension.

Agarose Gel Electrophoresis. Agarose gel electrophoresis was run at 110 volts for 45 min (Analytik Jena, Malaysia). First, the PCR products were loaded into
$1.5 \%$ agarose gel. Next, the gel was loaded with $4 \mu \mathrm{L}$ of TrackIt ${ }^{\mathrm{TM}} 1 \mathrm{~kb}$ DNA Ladder (Invitrogen, USA) as marker followed by $4 \mu \mathrm{L}$ of PCR product mixed with $1 \mu \mathrm{L}$ of TrackIt ${ }^{\mathrm{TM}}$ Cyan/Orange Loading Buffer (Invitrogen, USA), $4 \mu \mathrm{L}$ of negative control, and $4 \mu \mathrm{L}$ of positive control. The gel was then visualized using the Gel-doc ${ }^{\mathrm{TM}} \mathrm{XR}+$ System (Bio-Rad Laboratories, USA).

\section{Fusion Gene Sequencing and Phylogenetic} Analysis. The partial $F$ genes of the isolated NDV isolates were sent for Sanger sequencing (Repfon Glamor Sdn. Bhd., Malaysia). The raw sequences obtained were trimmed, edited, and assembled using BioEdit (Hall, 1999) to generate consensus sequences that were analyzed with the Basic Local Alignment Search Tool (BLAST) program [GenBank, National Center for Biotechnology Information (NCBI)]. The sequences of Malaysian NDV isolates were compared with reference strains representative of each genotype and subgenotype obtained from GenBank NCBI (Table 1 and Table 2) using the ClustalW method in MEGA v7.0 software. Then, phylogenetic trees were constructed using the maximum likelihood method based on the Kimura 2 parameter model (Tamura et al., 2011) with 1,000 bootstrap replicates.

Table 1

NDV reference strains representing the different classes and genotypes

\begin{tabular}{ccccc}
\hline Class & Genotype & Isolates/ strain & Accession number & Origin \\
\hline I & I & Teal/France/100011/2010 & JQ013039 & France \\
& & DE-R49/99 & DQ097393 & Hungary \\
\hline
\end{tabular}


Siti Nor Azizah Mahamud, Sheau Wei Tan, So-Youn Youn, Hyun-Jeong Lee, Ji- Youn Lee, Young-Kuk Kwon, Aini Ideris and Abdul Rahman Omar

Table 1 (Continued)

\begin{tabular}{|c|c|c|c|c|}
\hline Class & Genotype & Isolates/ strain & Accession number & Origin \\
\hline \multirow[t]{28}{*}{ II } & I & Ulster/67 & AY562991 & $\begin{array}{l}\text { Northern } \\
\text { Ireland }\end{array}$ \\
\hline & & V4 (Queensland) & M24693 & Australia \\
\hline & II & LaSota & DQ195265 & USA \\
\hline & & MB061/06 & GQ901891 & Malaysia \\
\hline & III & Mallard/CH/HLJ383/06 & KY776604 & China \\
\hline & & Miyadera & M24701 & Japan \\
\hline & IV & Herts/33 & AY741404 & UK \\
\hline & & Italien & EU293914 & Italy \\
\hline & V & Largo/71 & AY562990 & USA \\
\hline & & Anhinga/U.S (FI)/44083/93 & AY562986 & USA \\
\hline & VI & NDV05-028 & DQ439885 & China \\
\hline & & NDV05-029 & FJ766528 & China \\
\hline & VII & IBS002/11 & KF026013 & Malaysia \\
\hline & & IBS005/11 & KR074405 & Malaysia \\
\hline & & IBS025/13 & KT355595 & Malaysia \\
\hline & VIII & AF2204 & AF048763 & Malaysia \\
\hline & & MB085/05 & GQ901901 & Malaysia \\
\hline & & HR09 & MF285077 & China \\
\hline & IX & ZhJ-1/85 & AF458023 & China \\
\hline & & FJ-1/85 & AF458009 & China \\
\hline & XI & $\mathrm{MG} / 39 / 4 / 08$ & HQ266605 & Madagascar \\
\hline & & MG/MEOLA/08 & HQ266604 & Madagascar \\
\hline & XII & GD1003/2010 & KC152049 & China \\
\hline & & GD450/2011 & $\mathrm{KC} 152048$ & China \\
\hline & XIII & BD-C161/2010 & KY905320 & Bangladesh \\
\hline & & KW48/2011 & KU936209 & Bangladesh \\
\hline & XIV & NIE09-2014/2009 & HF969145 & Nigeria \\
\hline & & NIE09-2041/2009 & HF969149 & Nigeria \\
\hline
\end{tabular}


Table 1 (Continued)

\begin{tabular}{ccccc}
\hline Class & Genotype & Isolates/ strain & Accession number & Origin \\
\hline II & XVI & FO/499-31/505/2008 & MH392226 & Nigeria \\
& & $867-2 / 2008$ & JX186997 & Nigeria \\
& XVII & $228-7 / 2006$ & KF442614 & Nigeria \\
& & 903/KUDU-113/1992 & KU058680 & Nigeria \\
& XVIII & NIE10-171/2011 & HF969217 & Nigeria \\
& & CIV08-042/2007 & HF969218 & Ivory coast \\
\hline
\end{tabular}

Table 2

$N D V$ reference strains representing the different subgenotypes of NDV genotype VII

\begin{tabular}{|c|c|c|c|c|}
\hline $\begin{array}{l}\text { Diel et al. } \\
\text { (2012) }\end{array}$ & $\begin{array}{l}\text { Dimitrov et } \\
\text { al. (2019) }\end{array}$ & Isolates/ strain & $\begin{array}{l}\text { Accession } \\
\text { number }\end{array}$ & Origin \\
\hline \multirow[t]{3}{*}{ VIIb } & VII.1.1 & $\mathrm{Ck} / \mathrm{SD}-01-12-\mathrm{Ch}$ & KJ184594.1 & China \\
\hline & & $\mathrm{Ck} / \mathrm{JS}-17-11-\mathrm{Ch}$ & JQ013871.1 & China \\
\hline & & $\mathrm{Ck} / \mathrm{SD} 704 / 12$ & JX840454 & China \\
\hline \multirow[t]{2}{*}{ VIId } & VII.1.1 & $\mathrm{Ck} / \mathrm{MB} 016 / 07$ & GQ901894.1 & Malaysia \\
\hline & & $\mathrm{Ck} / \mathrm{MB} 064 / 05$ & GQ901893.1 & Malaysia \\
\hline \multirow[t]{2}{*}{ VIIe } & VII.1.1 & Go/GD/1/98 & AF456437.1 & China \\
\hline & & Ck/Ibaraki/SG106/1999 & AB853927.2 & Japan \\
\hline \multirow[t]{2}{*}{ VIIf } & VII.1.2 & $\mathrm{ND} / 03 / 018$ & GQ338309.1 & China \\
\hline & & $\mathrm{Ck} / \mathrm{ND} / 03 / 044$ & GQ338310.1 & China \\
\hline \multirow[t]{3}{*}{ VIIh } & VII. 2 & Ck/Makassar/003/09 & HQ697256.1 & Indonesia \\
\hline & & $\mathrm{Ck} / \mathrm{IBS} 005 / 11$ & KR074405.1 & Malaysia \\
\hline & & $\mathrm{Ck} / \mathrm{IBS} 002 / 11$ & KR074404.1 & Malaysia \\
\hline \multirow[t]{3}{*}{ VIIi } & VII. 2 & $\mathrm{Ck} /$ Banjarmasin/010/10 & HQ697254.1 & Indonesia \\
\hline & & $\begin{array}{c}\text { Ck/ } \\
\text { Kulonprogo/04171317/2017 }\end{array}$ & MK069429.1 & Indonesia \\
\hline & & $\mathrm{Ck} / \mathrm{IBS} 025 / 13$ & KT355595.1 & Malaysia \\
\hline \multirow[t]{2}{*}{ VIIj } & VII.1.1 & Dk/JLQG/2013 & KJ136259.1 & China \\
\hline & & $\mathrm{Ck} / \mathrm{JLJT} / 2012$ & KJ136258.1 & China \\
\hline \multirow[t]{3}{*}{ VIII } & VII.1.1 & Ck/IR/MAM81/2018 & MH481363.1 & Iran \\
\hline & & Ck/IR/MAM68/2017 & MH481361.1 & Iran \\
\hline & & Ck/IR/MAM55/2017 & MH247187.1 & Iran \\
\hline
\end{tabular}


Siti Nor Azizah Mahamud, Sheau Wei Tan, So-Youn Youn, Hyun-Jeong Lee, Ji- Youn Lee,

Young-Kuk Kwon, Aini Ideris and Abdul Rahman Omar

\section{Biological Characterization}

Mean Death Time (MDT). MDT is the average death time for the minimum lethal dose to kill all the inoculated SPF ECE. NDV isolates were classified as velogenic, mesogenic, and lentogenic according to mean embryo death time at $<60$ hours, 60 to 90 hours, and $>90$ hours, respectively (Alexander, 1988). Briefly, a ten-fold serial dilution of allantoic fluid of NDV isolates was prepared in $1 \mathrm{x}$ sterile PBS $\left(10^{-1}\right.$ to $\left.10^{-10}\right)$. Then, $0.1 \mathrm{~mL}$ of the inoculum was injected into the allantoic cavity of 10-day-old SPF eggs. The infected SPF eggs were incubated at $37^{\circ} \mathrm{C}$ for five days with daily candling to monitor embryonic death.

\section{Intracerebral Pathogenicity Index (ICPI).}

ICPI is the mean score of daily observations of each inoculated chick over eight days. NDV isolates were classified as velogenic strains with an ICPI of 1.5-2.0, mesogenic with an ICPI of 0.5-1.5, and lentogenic with an ICPI $<0.5$ (OIE, 2012). Briefly, the allantoic fluid with a HA titer $>2^{4}$ was diluted into sterile PBS (1/10). Then $0.05 \mathrm{~mL}$ of the inoculum was injected intracerebrally into 10 SPF chicks aged 24 to 40 hours old (Alexander \& Senne, 2008; OIE, 2012).

\section{RESULTS}

\section{Collection of Samples from Different Bird Species and Commercial Chickens}

A total of 150 swab samples collected from 15 different species of migratory birds, local birds, and resident birds in bird sanctuaries and along with 20 samples from suspected cases of ND in commercial chickens, were screened for NDV detection. All the nonpoultry birds were clinically healthy and not showing any overt clinical signs, while the commercial poultry birds were clinically ill and suspected of having ND (Table 3 and Table 4).

\section{Virus Isolation and RT-PCR}

Based on the virus isolation performed, a total of five cases from commercial chickens and one case from non-poultry birds (black swans) with IDs of UPM/NDV/ IBS303/2016, UPM/NDV/IBS380/2017, UPM/NDV/IBS362/2016, UPM/NDV/ IBS501/2017, UPM/NDVIBS599/2017, and UPM/NDV/IBS932/2017 were found to be positive for NDV. These isolates showed consistent embryonic mortality with an increased number of dead embryos following three serial passages, positives on the HA spot test and positives on the RT-PCR (Table 3). One sample from non-poultry species showed embryonic mortality and was positive on the HA spot test. However, the sample gave a negative result on RT-PCR. Meanwhile, all the other samples from non-poultry species were negative for NDV, with inconsistent or no embryonic mortality and negatives on the HA spot test and RT-PCR. The examination of the dead embryos showed lesions, small embryos with cranial hemorrhages, and cloudy allantoic fluid with the presence of petechial hemorrhages on the yolk sac (data not shown). 
Isolation and Characterization of NDV Subgenotype VII.2/VIIi

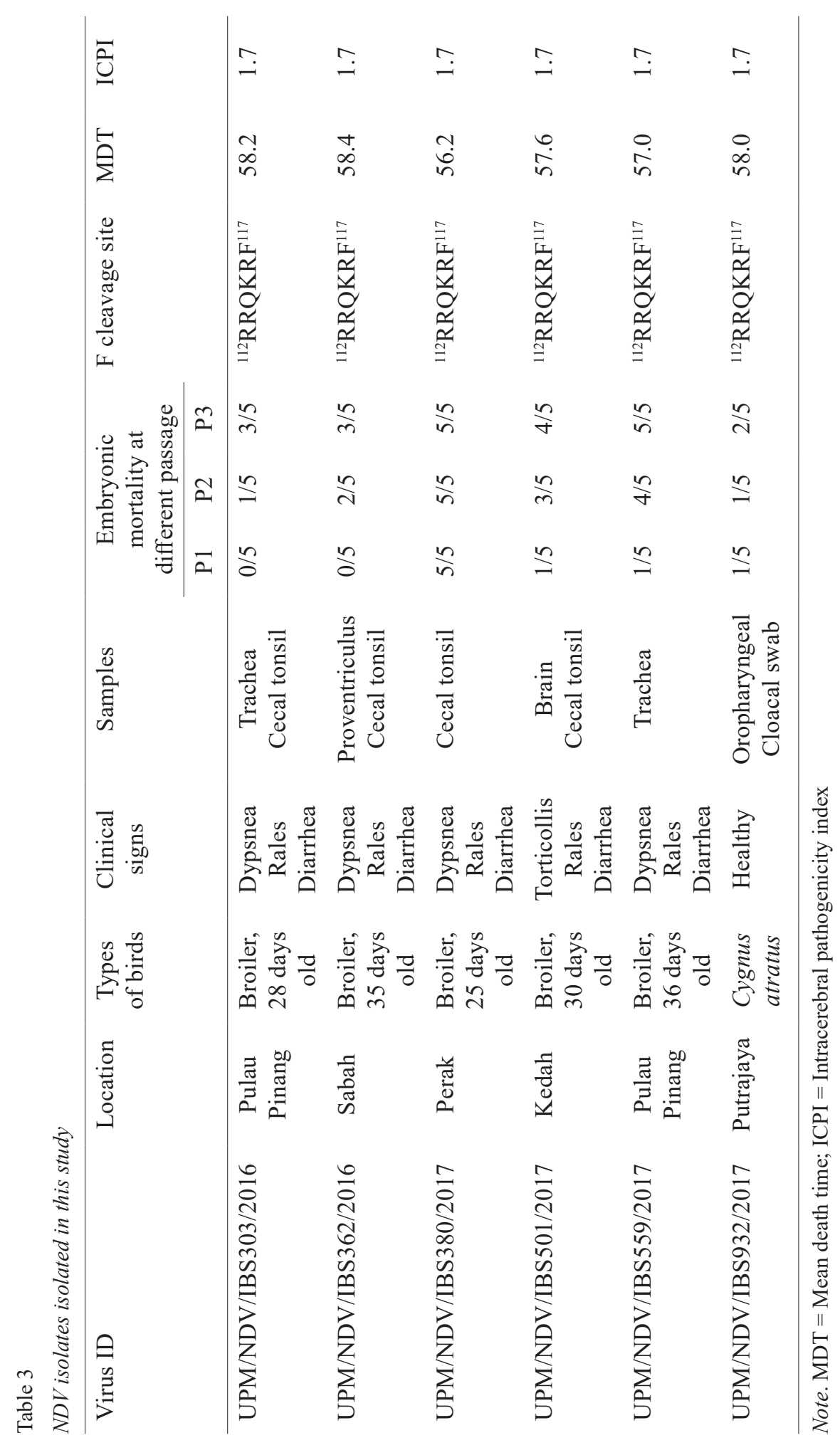

Pertanika J. Trop. Agric. Sci. 44 (4): 879 - 898 (2021) 
Siti Nor Azizah Mahamud, Sheau Wei Tan, So-Youn Youn, Hyun-Jeong Lee, Ji- Youn Lee, Young-Kuk Kwon, Aini Ideris and Abdul Rahman Omar

Table 4

Detection of HA activities and RT-PCR assay to confirm NDV in non-poultry bird species

\begin{tabular}{|c|c|c|c|c|c|c|}
\hline \multirow[t]{2}{*}{ Species } & \multirow[t]{2}{*}{ Origin } & \multicolumn{3}{|c|}{$\begin{array}{c}\text { Embryonic mortality at } \\
\text { different passage }\end{array}$} & \multirow[t]{2}{*}{$\begin{array}{l}\text { HA spot } \\
\text { test }\end{array}$} & \multirow[t]{2}{*}{ RT-PCR } \\
\hline & & P1 & P2 & P3 & & \\
\hline Actitis hypoleucos & Selangor & $0 / 5$ & $0 / 5$ & $0 / 5$ & -ve & -ve \\
\hline Xenus cinereus & Selangor & $0 / 5$ & $0 / 5$ & $0 / 5$ & -ve & -ve \\
\hline Tringa totanus & Selangor & $0 / 5$ & $0 / 5$ & $0 / 5$ & -ve & -ve \\
\hline $\begin{array}{l}\text { Charadrius } \\
\text { leschenaultii }\end{array}$ & Selangor & $0 / 5$ & $0 / 5$ & $0 / 5$ & -ve & -ve \\
\hline Vanellus indicus & Selangor & $0 / 5$ & $0 / 5$ & $0 / 5$ & -ve & $-\mathrm{ve}$ \\
\hline Charadrius mongolus & Selangor & $0 / 5$ & $0 / 5$ & $0 / 5$ & $-\mathrm{ve}$ & $-\mathrm{ve}$ \\
\hline Vanellus indicus & Selangor & $0 / 5$ & $0 / 5$ & $0 / 5$ & - ve & $-\mathrm{ve}$ \\
\hline Charadrius mongolus & Selangor & $0 / 5$ & $0 / 5$ & $0 / 5$ & $-\mathrm{ve}$ & $-\mathrm{ve}$ \\
\hline Caprimulgus affinis & Selangor & $0 / 5$ & $0 / 5$ & $0 / 5$ & -ve & $-v e$ \\
\hline Calidris minuta & Selangor & $0 / 5$ & $1 / 5$ & $1 / 5$ & $+\mathrm{ve}$ & -ve \\
\hline Numenius phaeopus & Perak & $0 / 5$ & $0 / 5$ & $0 / 5$ & -ve & -ve \\
\hline Butorides striata & Perak & $0 / 5$ & $0 / 5$ & $0 / 5$ & -ve & -ve \\
\hline Egretta garzetta & Perak & $0 / 5$ & $0 / 5$ & $0 / 5$ & -ve & -ve \\
\hline Halcyon pileata & Perak & $0 / 5$ & $0 / 5$ & $0 / 5$ & -ve & -ve \\
\hline Cygnus atratus & Putrajaya & $1 / 5$ & $1 / 5$ & $2 / 5$ & $+\mathrm{ve}$ & $+\mathrm{ve}$ \\
\hline
\end{tabular}

Note. $\mathrm{HA}=$ Hemagglutination; RT-PCR $=$ Reverse transcriptase-polymerase chain reaction

\section{RT-PCR Amplification of Fusion Gene}

The partial F genes of the NDV isolates were amplified with the expected amplicon size of 535 bp (Figure 1). All six samples were then sent for Sanger sequencing (MATRIOUX, Malaysia) of the partial $F$ gene.

\section{Phylogenetic Analysis of Fusion Gene}

The Malaysian NDV isolates are closely related to the previously characterized genotype VII NDV with $>96.0 \%$ identity based on the partial $F$ gene sequence alignment. The phylogenetic tree was generated based on 535 bp of the F gene segment corresponding to nucleotide position 47 to position 535, including the F cleavage site compared to NDV genotype I-XVIII as the reference strains. The phylogenetic tree analysis showed that all the identified NDV isolates were clustered into a single genotype VII (Figure 2) and subgenotype VII.2 /VIIi (Figure 3). 


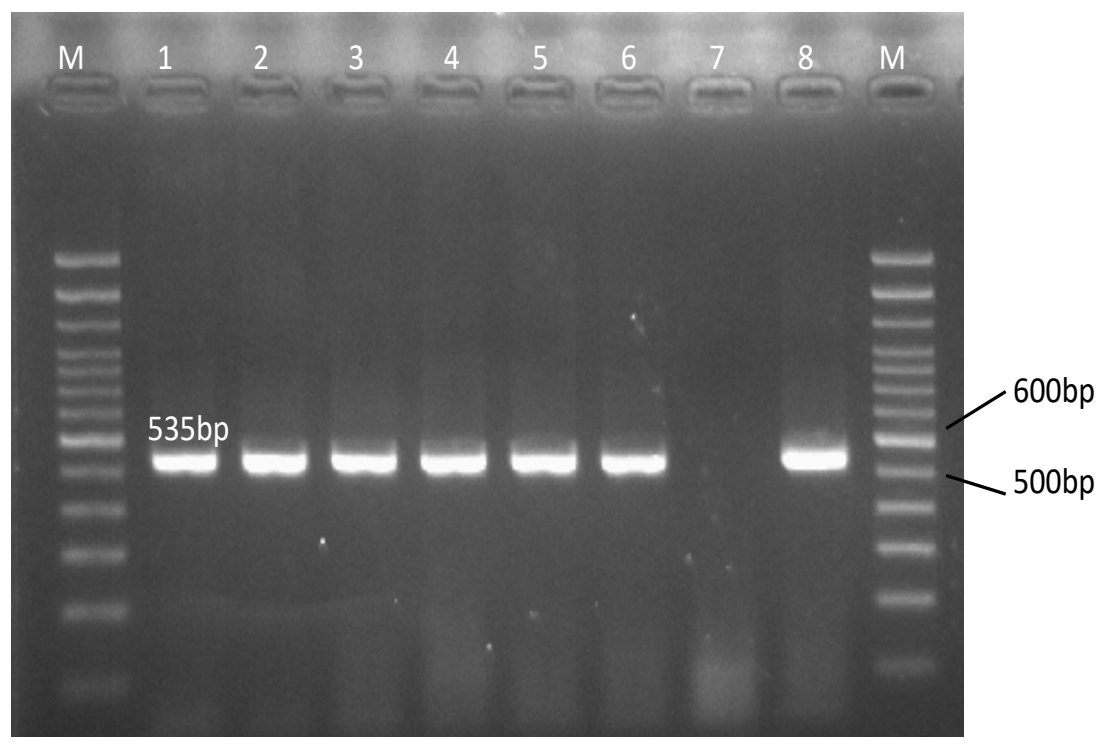

Figure 1. Agarose gel electrophoresis of NDV isolates: UPM/NDV/IBS380/2017 (lane 1), UPM/NDV/IBS599/2017 (lane 2), UPM/NDV/IBS362/2016 (lane 3), UPM/NDV/IBS501/2017 (lane 4), UPM/NDV/IBS303/2016 (lane 5), UPM/NDV/IBS932/2017 (lane 6), non-template control NTC (lane 7), and positive control LaSota (lane 8). Lane $\mathrm{M}$ is a molecular weight ladder

The pathotypes of the NDV isolates were then analyzed based on the amino acid sequences of the $\mathrm{F}$ cleavage site using MEGA v7.0. The analysis showed that all the identified NDV isolates were velogenic with the presence of multiple basic amino acid residues at position ${ }^{112} \mathrm{RRQKRF}{ }^{117}$, MDT of $<60$ hours, and an ICPI of 1.7.

\section{Pairwise Evolutionary Distances}

The pairwise evolutionary distance was constructed using the maximum composite likelihood model to estimate mean distances between newly isolated subgenotype VIIi isolates and subgenotypes VIIb, VIId, VIIe, VIIf, VIIh, VIIi, VIIl, and VIIj. Evolutionary distance estimation of nucleotides proved that Malaysia VIIi isolates are distinct from the previously reported subgenotype VIIi at 0.030 to 0.075 and other subgenotypes at 0.076 to 0.140 (Table 5). In addition, the amino acids are distinct from VIIi at 0.076 to 0.130 and other subgenotypes at 0.169 to 0.305 (Table 5), suggesting the newly isolated subgenotypes VIIi from this study have evolved from the same ancestor of the previously isolated subgenotypes VIIi. In addition, of all six NDV isolates, three isolates UPM/NDV/ IBS 362/2016, UPM/NDV/IBS501/2017, and UPM/NDV/IBS599/2017, shared the highest nucleotide and amino acid identity with reference subgenotype VII.2 (VIIi) at $97 \%$ and $92.4 \%$, respectively. Meanwhile, 
Siti Nor Azizah Mahamud, Sheau Wei Tan, So-Youn Youn, Hyun-Jeong Lee, Ji- Youn Lee, Young-Kuk Kwon, Aini Ideris and Abdul Rahman Omar

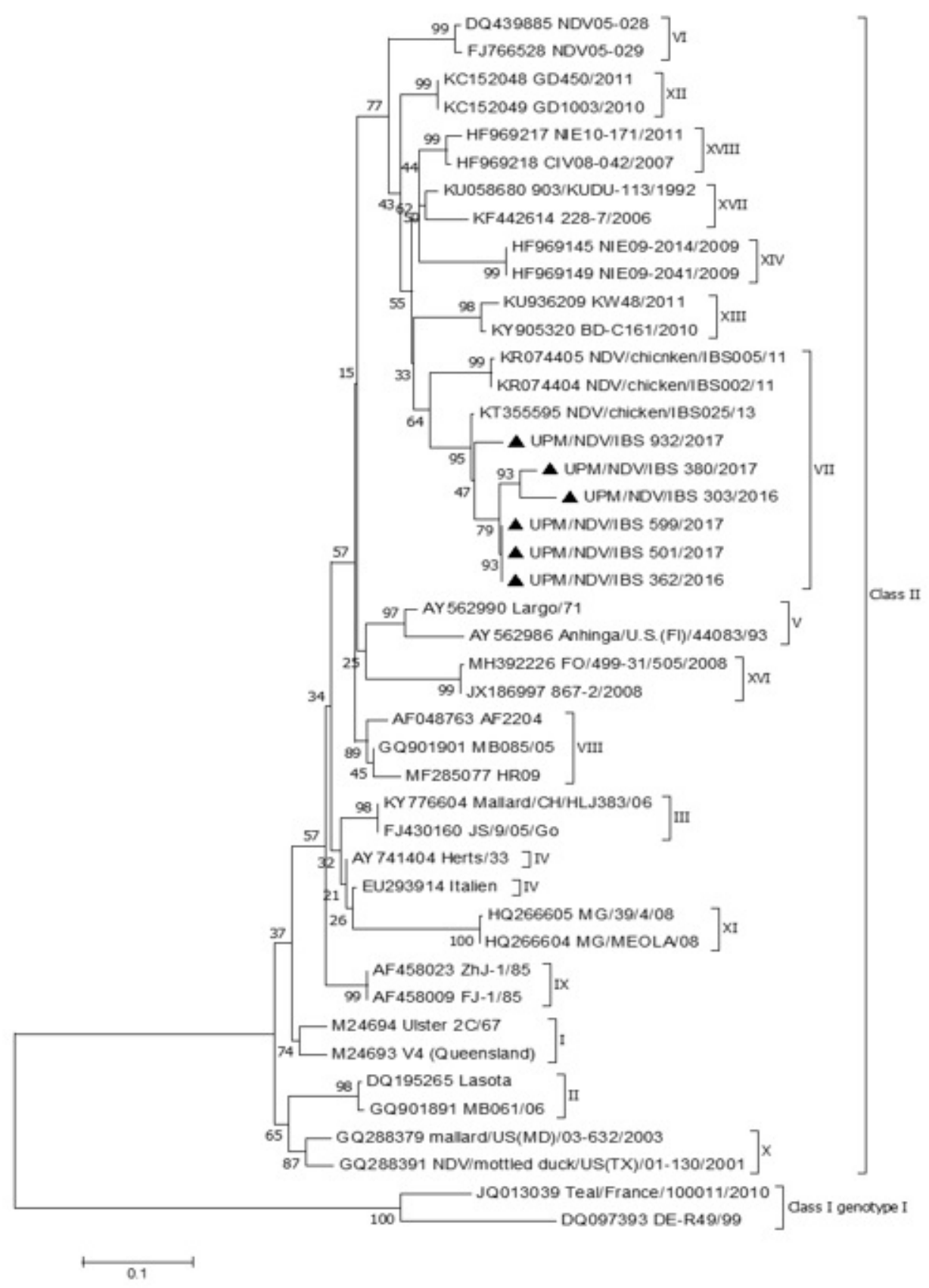

Figure 2. Phylogenetic analysis of the NDV isolates identified in this study (marked with $\mathbf{\Delta}$ ), and 36 previously characterized isolates representing Class I and Class II NDV genotypes. The tree was inferred using the maximum likelihood method based on the Kimura-2 parameter model (1,000 bootstrap replicates) using MEGA v7.0 software. 


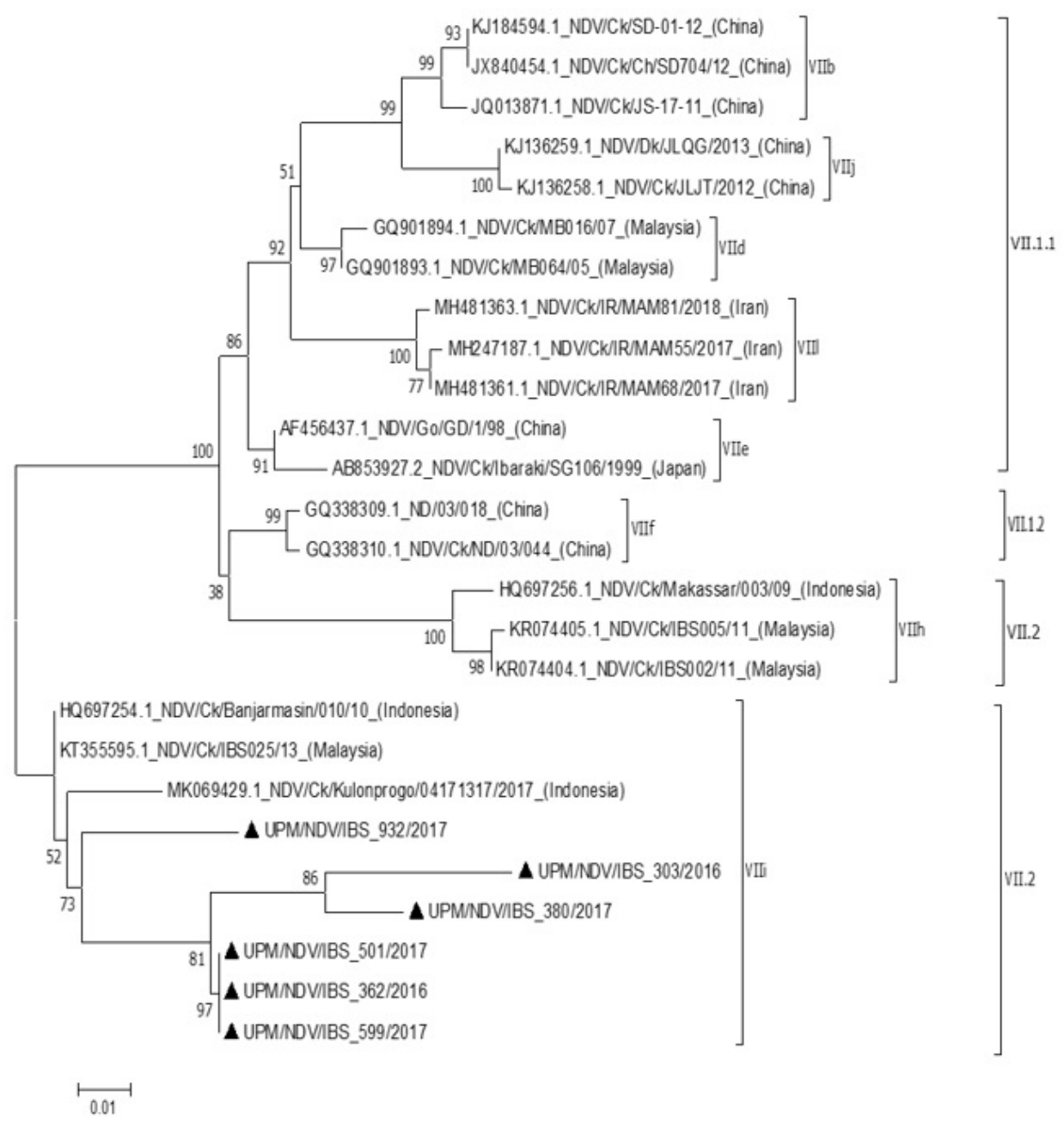

Figure 3. Phylogenetic analysis of the NDV subgenotype VII according to Diel et al.'s (2012) classification system (VIIb-VIIi) and Dimitrov et al.'s (2019) classification system (VII.1 -VII.2). NDV isolates identified in this study (marked with $\boldsymbol{\Delta}$ ) and 20 previously characterized isolates representing NDV subgenotypes VII.

isolate UPM/NDV/IBS303/2016 showed $89 \%$, respectively, and isolate UPM/NDV/ $93.6 \%$ and $89 \%$, respectively; isolate UPM/ IBS $932 / 2017$ showed $92.5 \%$ and $87 \%$, NDV/IBS380/2017 showed $94.1 \%$ and respectively. 
Siti Nor Azizah Mahamud, Sheau Wei Tan, So-Youn Youn, Hyun-Jeong Lee, Ji- Youn Lee, Young-Kuk Kwon, Aini Ideris and Abdul Rahman Omar

$\frac{5}{3}$

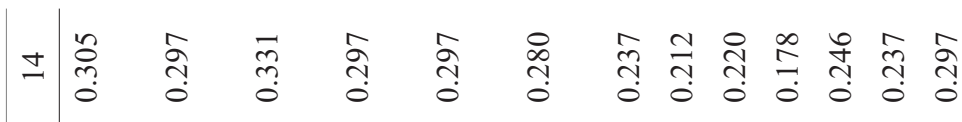

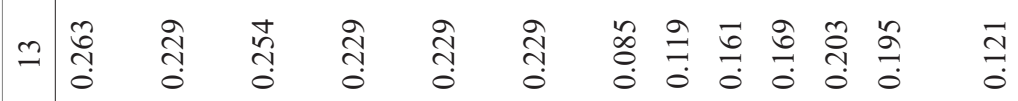

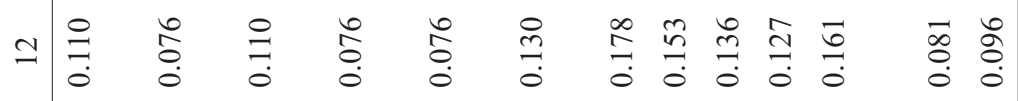

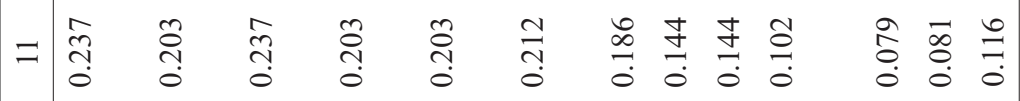

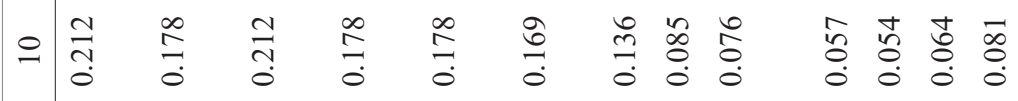

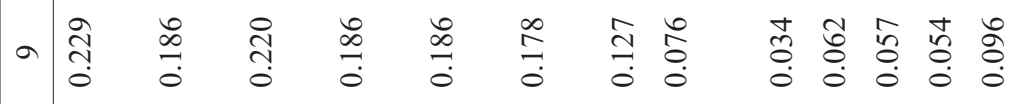

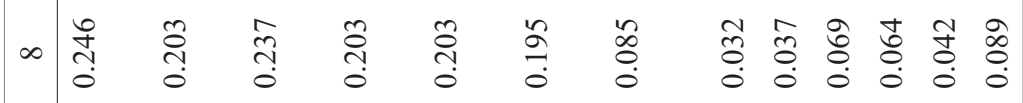

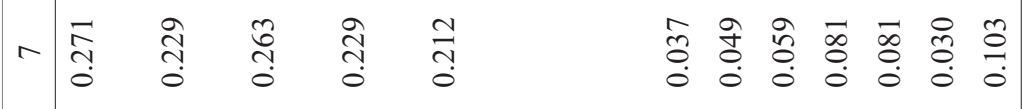

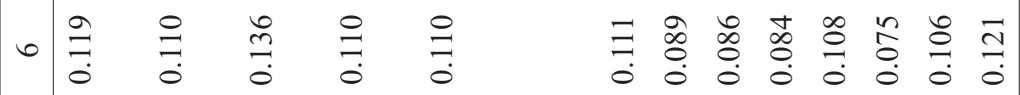

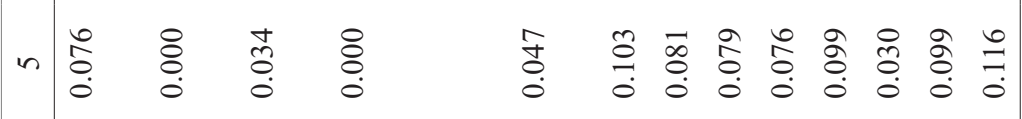

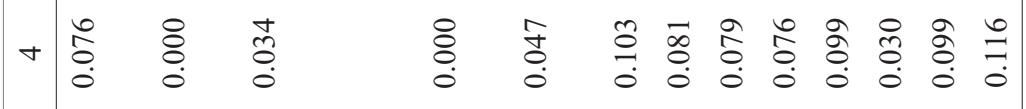

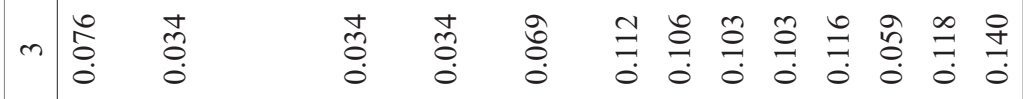

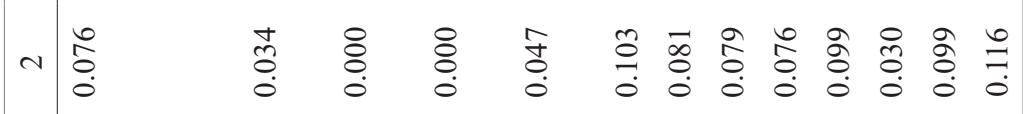

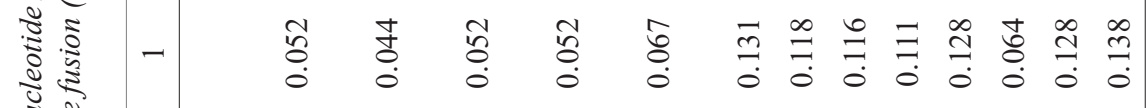

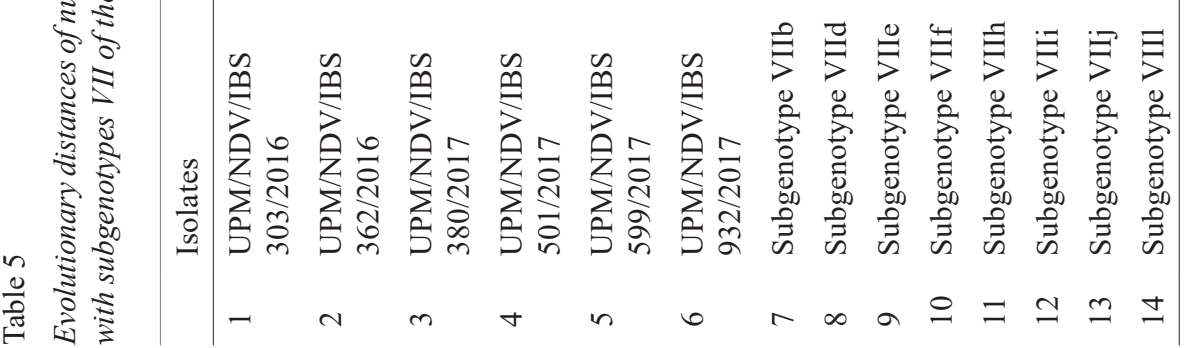




\section{DISCUSSION}

ND has been endemic in Malaysia for decades since its first detection in 1934. Implementing a good flock health program, including a mass vaccination regime on poultry farms, can decrease ND outbreaks; however, the disease is a major threat to the industry. The result of continuing surveillance among commercial poultry farms indicates that genotype VII is the predominant strain that has been causing ND outbreaks around Malaysia since the 2000s, although viruses from genotype I, III, VI, and VIII have also been reported (Shohaimi et al., 2015).

According to OIE reports, Malaysia has experienced several major ND outbreaks in commercial poultry flocks. Since 1999 , ND has been caused by avirulent and virulent genotypes. NDV genotypes I, II, III, VI, VII, and VIII have been reported in commercial poultry (Aljumaili et al., 2017; Berhanu et al., 2010; Roohani et al., 2015; Satharasinghe et al., 2016; Shohaimi et al., 2015; Tan et al., 2009, 2010). The subgenotype VII.2 (VIIh and VIIi) NDVs, which have caused the fifth ND panzootic outbreak, has been endemic in Southeast Asia, including Malaysia (Berhanu et al., 2010), Indonesia (Doan et al., 2020; Xiao et al., 2012), Vietnam (Choi et al., 2014; Le et al., 2018), Cambodia (Choi et al., 2013), and then spread to other countries (Liu et al., 2015).

There is limited information available regarding the detection of NDV in nonpoultry birds, including wild birds in Malaysia. Nevertheless, previous studies have reported the detection of genotype III in peacocks, genotype VI in pigeons, genotype VII in peacocks, owls, and egrets (Shohaimi et al., 2015) as well as genotype II in parrots (Berhanu et al., 2010) in Malaysia. However, not much is known about the role of wild bird reservoirs in the exchange of virulent ND among wild birds and poultry species in Malaysia. In this study, six isolates of subgenotype VII.2/VIIi were isolated from commercial chicken farms (broiler) and wetland (black swan). According to amino acid residues at the $\mathrm{F}$ gene cleavage site, the six isolates were identified as virulent strains with the motif of ${ }^{112}{ }^{12 R Q K R F}{ }^{117}$, an identification supported by results from MDT and ICPI.

Several studies have reported increasing NDV genotype VII detection among waterfowl, especially in China and Taiwan (Ke et al., 2010; Zhang et al., 2010). However, the severity of infection varies depending on the virus, host, age, co-infection, host's immune status, and environmental condition, as Alexander (2009) explained. Kaleta and Kummerfeld (2012) reported that healthy white storks could harbor virulent NDV genotype VII and thus potentially serve as a reservoir in spreading virulent NDV to susceptible bird species. Xie et al. (2012) reported a similar situation, in which NDV subgenotype VIIa was isolated from healthy wild egrets in China. Meanwhile, Vidanović et al. (2011) isolated NDV subgenotype VIId in dead mallard, feral rock pigeon, Eurasian sparrowhawk, and Eurasian collared dove during an ND outbreak in 
Serbia, while Wajid et al. (2017) isolated NDV subgenotype VIIi from clinically ill wild pigeon and black swan in Pakistan. However, in another study, Wajid et al. (2018) isolated NDV subgenotype VIIi from clinically healthy wild duck, geese, and black swans in Pakistan. In contrast, Miller et al. (2015) isolated NDV subgenotype VIIi from pheasants, peacocks, parakeets, parrots, and pigeons in Pakistan, showing tremors and paralysis with $60 \%$ mortality. In this study, the velogenic NDV isolated from a black swan in the wetland area in Putrajaya does not show any obvious clinical signs. Further research to sequence the complete genome of the viruses is required to get more information regarding the epidemiology of the virus, as this study only addressed partial $\mathrm{F}$ gene sequencing.

Molecular characterization of $\mathrm{F}$ genes, especially the F cleavage site, is a reliable test for determining the pathotypes of the NDV strains (Toyoda et al., 1987) and genotype classification (Diel et al., 2012; Dimitrov et al., 2019). Based on the constructed phylogenetic tree (Figure 2), the studied NDV isolates were clustered into class II genotype VII as subgenotype VII.2/VIIi (Figure 3). This result is in line with previous studies that indicated NDV genotype VIIi or VII.2 is responsible for the fifth ND panzootic outbreak (Courtney et al., 2013; Lu et al., 2014; Miller et al., 2015; Zhang et al., 2010). The studies also indicated that subgenotype VIIi is circulating among commercial chickens and wild birds in Asia (Miller et al., 2015; Putri et al., 2017; Umali et al., 2017; Xiao et al.,
2012). In addition, the detection of multiple basic amino acids at positions 112 to 116 and a phenylalanine residue at position 117 $\left({ }^{112} \mathrm{RRQKRF}{ }^{117}\right)$ in the new isolates indicates the viruses are virulent.

According to OIE (2012), virus isolation is the standard gold method for NDV isolation and identification via inoculation into SPF ECE. This step allows NDVs to adapt in the embryonated eggs and grow to a higher virus titer. In this study, five samples from commercial chickens (UPM/NDV/IBS303/2016, UPM/NDV/ IBS380/2017, UPM/NDV/IBS362/2016, UPM/NDV/IBS501/2017, and UPM/ NDV/IBS599/2017) and one sample from non-poultry, black swans (UPM/NDV/ IBS932/2017) showed constant embryonic mortality following three viral passages. Meanwhile, the remaining samples from wild birds showed inconsistent or no embryonic mortality patterns. As expected, only samples consistently showing embryonic mortality were found to be positive by a HA spot test and confirmed by RT-PCR using NDV specific F gene primers.

One sample from wild birds, Calidris minuta, showed mild on the HA test but negative for RT-PCR (Table 4), indicating the presence of other avian viruses. The HA spot test is a direct and visible macroscopic test that detects agglutination of chicken red blood cells (RBCs) but does not identify the etiological agent present in the allantoic sample tested. The HA spot test is commonly practiced in the laboratory to test for selected viruses that have hemagglutinin protein such as NDV, avian influenza virus (AIV), and 
egg drop syndrome (EDS) (OIE, 2018). However, further studies failed to detect avian influenza virus (AIV), infectious bronchitis, and fowl adenovirus (data not shown). A HA spot test gives positive results when haemagglutinin on the surface of NDV binds to chicken RBCs, producing clumping or hemagglutination. However, there is a possibility of getting a false-positive result when a nonspecific reaction occurs in tested samples. In addition, the HA spot test does not distinguish between infectious viral particles and degraded viral particles since both particles can cause hemagglutination (OIE, 2012).

\section{CONCLUSION}

This study isolated NDV subgenotype VII.2 (VIIi) from commercial chicken and non-poultry birds, indicating that the current ND infection in Malaysia is caused by subgenotype VII.2 (VIIi). The same trend has been observed in neighboring countries such as Indonesia, the Philippines, Vietnam, and Cambodia, along with fifth ND panzootic outbreaks across Asia. However, the epidemiological link to the detection of the viruses in different avian species is not clear. Therefore, further studies are required to gain insight into the importance of non-poultry birds, including wild birds, as the source of virulent NDV in poultry in Malaysia.

\section{ACKNOWLEDGMENTS}

This study was funded by the Higher Institution Centre of Excellence (HICoE) grant number 6369101, Ministry of Higher Education, Government of Malaysia, and grant number I-1543084-2017-19-01 and I-1543084-2020-22-01 Animal and Plant Quarantine Agency (APQA), Republic of Korea.

\section{REFERENCES}

Alexander, D. J. (1988). Newcastle disease diagnosis. In D. J. Alexander (Ed.), Newcastle disease: Developments in veterinary virology (pp. 147161). Springer. https://doi.org/10.1007/978-14613-1759-3_9

Alexander, D. J. (2009). Ecology and epidemiology of Newcastle disease. In I. Capua \& D. J. Alexander (Eds.), Avian influenza and Newcastle disease (pp. 19-26). Springer. https://doi.org/10.1007/978-88-470-0826-7_2

Alexander, D. J., \& Senne, D. A. (2008). Newcastle disease, other avian paramyxoviruses, and pneumovirus infections. In Y. M. Saif, A. M. Fadly, J. R. Glisson, L. R. McDougald, L. K. Nolan, \& D. E. Swayne (Eds.), Disease of poultry (12th ed., pp. 75-115). Blackwell.

Aljumaili, O. A., Yeap, S. K., Omar, A. R., \& Aini, I. (2017). Isolation and characterization of genotype VII Newcastle disease virus from NDV vaccinated farms in Malaysia. Pertanika Journal of Tropical Agricultural Science, 40(4), 677-690.

Berhanu, A., Ideris, A., Omar, A. R., \& Bejo, M. H. (2010). Molecular characterization of partial fusion gene and C-terminus extension length of haemagglutinin-neuraminidase gene of recently isolated Newcastle disease virus isolates in Malaysia. Virology Journal, 7(1), 183. http:// www.virologyj.com/content/7/1/183

Choi, K. S., Kye, S. J., Kim, J. Y., Damasco, V. R., Sorn, S., Lee, Y. J., Choi, J. G., Kang, H. M., Kim, K. I., Song, B. M., \& Lee, H. S. (2013). Molecular epidemiological investigation of 
Siti Nor Azizah Mahamud, Sheau Wei Tan, So-Youn Youn, Hyun-Jeong Lee, Ji- Youn Lee, Young-Kuk Kwon, Aini Ideris and Abdul Rahman Omar

velogenic Newcastle disease viruses from village chickens in Cambodia. Virus Genes, 47(2), 244249. https://doi.org/10.1007/s11262-013-0930-2

Choi, K. S., Kye, S. J., Kim, J. Y., To, T. L., Nguyen, D. T., Lee, Y. J., Choi, J. G., Kang, H. M., Kim, K. I., Song, B. M., \& Lee, H. S. (2014). Molecular epidemiology of Newcastle disease viruses in Vietnam. Tropical Animal Health and Production, 46(1), 271-277. https://doi. org/10.1007/s11250-013-0475-3

Courtney, S. C., Susta, L., Gomez, D., Hines, N. L., Pedersen, J. C., Brown, C. C., Miller, P. J., \& Afonso, C. L. (2013). Highly divergent virulent isolates of Newcastle disease virus from the Dominican Republic are members of a new genotype that may have evolved unnoticed for over 2 decades. Journal of Clinical Microbiology, 51(2), 508-517. https://doi. org/10.1128/JCM.02393-12

Diel, D. G., da Silva, L. H., Liu, H., Wang, Z., Miller, P. J., \& Afonso, C. L. (2012). Genetic diversity of avian paramyxovirus type 1: Proposal for a unified nomenclature and classification system of Newcastle disease virus genotypes. Infection, Genetics and Evolution, 12(8), 1770-1779. https://doi.org/10.1016/j.meegid.2012.07.012.

Dimitrov, K. M., Abolnik, C., Afonso, C. L., Albina, E., Bahl, J., Berg, M., Briand, F. X., Brown, I. H., Choi, K. S., Chvala, I., Diel, D. G., Durr, P. A., Ferreira, H. L., Fusaro, A., Gil, P., Goujgoulova, G. V., Grund, C., Hicks, J. T., Joannis, T. M., ... Wong, F. (2019). Updated unified phylogenetic classification system and revised nomenclature for Newcastle disease virus. Infection, Genetics and Evolution, 74, 103917. https://doi.org/10.1016/j.meegid.2019.103917

Doan, P. T. K., Cahyono, M. I., Rabiei, M., Pandarangga, P., McAllister, M. M., Low, W. Y., Tearle, R., Dharmayanti, I., Tarigan, S., Indriani, R., Ignjatovic, J., \& Hemmatzadeh, F. (2020). Genome sequences of Newcastle disease virus strains from two outbreaks in Indonesia.
Microbiology Resource Announcements, 9(23), e00205-20. https://doi.org/10.1128/MRA.0020520

Hall, T. (1999). BioEdit: A user-friendly biological sequence alignment editor and analysis program for Windows 95/98/NT. Nucleic Acids Symposium Series, 41, 95-98.

Herczeg, J., Wehmann, E., Bragg, R. R., Dias, P. T., Hadjiev, G., Werner, O., \& Lomniczi, B. (1999). Two novel genetic groups (VIIb and VIII) responsible for recent Newcastle disease outbreaks in Southern Africa, one (VIIb) of which reached Southern Europe. Archives of Virology, 144(11), 2087-2099. https://doi. org/10.1007/s007050050624

International Committee on Taxonomy of Viruses. (2019). Virus taxonomy. https://talk.ictvonline. org/taxonomy/

Jaganathan, S., Ooi, P. T., Phang, L. Y., Allaudin, Z. N. B., Yip, L. S., Choo, P. Y., Lim, B. K., Lemiere, S., \& Audonnet, J. C. (2015). Observation of risk factors, clinical manifestations and genetic characterization of recent Newcastle disease virus outbreak in West Malaysia. BMC Veterinary Research, 11(1), 219. https://doi. org/10.1186/s12917-015-0537-z

Kaleta, E. F., \& Kummerfeld, N. (2012). Isolation of herpesvirus and Newcastle disease virus from White Storks (Ciconia ciconia) maintained at four rehabilitation centres in northern Germany during 1983 to 2001 and failure to detect antibodies against avian influenza A viruses of subtypes H5 and $\mathrm{H} 7$ in these birds. Avian Pathology, 41(4), 383-389. https://doi.org/10.1 080/03079457.2012.696312

Kaleta, E. F., Alexander, D. J. and Russell, P. H. (1985). The first isolation of the avian pmv-1 virus responsible for the current panzootic in pigeons?. Avian Pathology, 14(4), 553-557. https://doi.org/10.1080/03079458508436258 
Ke, G. M., Chuang, K. P., Chang, C. D., Lin, M. Y., \& Liu, H. J. (2010). Analysis of sequence and haemagglutinin activity of the HN glycoprotein of Newcastle disease virus. Avian Pathology, 39(3), 235-244. https://doi. org/10.1080/03079451003789331

Kraneveld, F. C. (1926). A poultry disease in the Dutch East Indies. Nederlandsch-Indische Bladen voor Diergeneeskunde, 38, 448-450.

Le, X. T. K., Doan, H. T. T., \& Le, T. H. (2018). Molecular analysis of Newcastle disease virus isolates reveals a novel XIId subgenotype in Vietnam. Archives of Virology, 163(11), 31253130. https://doi.org/10.1007/s00705-0183961-0

Liu, M. M., Cheng, J. L., Yu, X. H., Qin, Z. M., Tian, F. L., \& Zhang, G. Z. (2015). Generation by reverse genetics of an effective attenuated Newcastle disease virus vaccine based on a prevalent highly virulent Chinese strain. Biotechnology Letters, 37(6), 1287-1296. https:// doi.org/10.1007/s10529-015-1799-Z

Lomniczi, B., Wehmann, E., Herczeg, J., BallagiPordany, A., Kaleta, E. F., Werner, O., Meulemans, G., Jorgensen, P. H., Mante, A. P., Gielkens, A. L. J., \& Capua, I. (1998). Newcastle disease outbreaks in recent years in western Europe were caused by an old (VI) and a novel genotype (VII). Archives of Virology, 143(1), 49-64. https://doi.org/10.1007/s007050050267

Lu, A., Diao, Y., Chen, H., Wang, J., Ge, P., Sun, X., \& Hao, D. (2014). Evaluation of histopathological changes, viral load and immune function of domestic geese infected with Newcastle disease virus. Avian Pathology, 43(4), 325-332. https:// doi.org/10.1080/03079457.2014.931928.

Miller, P. J., Haddas, R., Simanov, L., Lublin, A., Rehmani, S. F., Wajid, A., Bibi, T., Khan, T. A., Yaqub, T., Setiyaningsih, S., \& Afonso, C. L. (2015). Identification of new sub-genotypes of virulent Newcastle disease virus with potential panzootic features. Infection, Genetics and
Evolution, 29, 216-229. https://doi.org/10.1016/j. meegid.2014.10.032

Putri, D. D., Handharyani, E., Soejoedono, R. D., Setiyono, A., Mayasari, N. L. P. I., \& Poetri, O. N. (2017). Pathotypic characterization of Newcastle disease virus isolated from vaccinated chicken in West Java, Indonesia. Veterinary World, 10(4), 438-444. https://doi.org/10.14202/ vetworld.2017.438-444

Roohani, K., Tan, S. W., Yeap, S. K., Ideris, A., Bejo, M. H., \& Omar, A. R. (2015). Characterisation of genotype VII Newcastle disease virus (NDV) isolated from NDV vaccinated chickens, and the efficacy of LaSota and recombinant genotype VII vaccines against challenge with velogenic NDV. Journal of Veterinary Science, 16(4), 447-457. https://doi.org/10.4142/jvs.2015.16.4.447

Satharasinghe, D. A., Murulitharan, K., Tan, S. W., Yeap, S. K., Munir, M., Ideris, A., \& Omar, A. R. (2016). Detection of inter-lineage natural recombination in avian paramyxovirus serotype 1 using simplified deep sequencing platform. Frontiers in Microbiology, 7, 1907. https://doi. org/10.3389/fmicb.2016.01907

Shohaimi, S. A., Raus, R. A., Huai, O. G., Asma Yatim, B. M., Nayan, N., \& Yusuf, A. M. (2015). Sequence and phylogenetic analysis of Newcastle disease virus genotype VII isolated in Malaysia during 1999-2012. Jurnal Teknologi, 77(25). https://doi.org/10.11113/jt.v77.6757

Tamura, K., Peterson, D., Peterson, N., Stecher, G., Nei, M., \& Kumar, S. (2011). MEGA5: Molecular evolutionary genetics analysis using maximum likelihood, evolutionary distance, and maximum parsimony methods. Molecular Biology and Evolution, 28(10), 2731-2739. https://oi.org/10.1093/molbev/msr121

Tan, S. W., Aini, I., Omar, A. R., Yusoff, K., HairBejo, M. (2009). Detection and differentiation of Newcastle disease virus using SYBR Green I real-time PCR with novel nucleocapsid gene 
specific primer. Journal Virology Methods, 160(1-2), 149-156. https://doi.org/10.1016/j. jviromet.2009.05.006

Tan, S. W., Ideris, A., Omar, A. R., Yusoff, K., \& HairBejo, M. (2010). Sequence and phylogenetic analysis of Newcastle disease virus genotypes isolated in Malaysia between 2004 and 2005. Archives of Virology, 155(1), 63-70. https://doi. org/10.1007/s00705-009-0540-4

Toyoda, T., Sakaguchi, T., Imai, K., Inocencio, N. M., Gotoh, B., Hamaguchi, M., \& Nagai, Y. (1987). Structural comparison of the cleavage-activation site of the fusion glycoprotein between virulent and avirulent strains of Newcastle disease virus. Virology, 158(1), 242-247. https://doi. org/10.1016/0042-6822(87)90261-3

Turan, N., Ozsemir, C., Yilmaz, A., Cizmecigil, U. Y., Aydin, O., Bamac, O. E., Gurel, A., Kutukcu, A., Ozsemir, K., Tali, H.E., Tali, B.H., \& Yilmaz, H. (2020). Identification of Newcastle disease virus subgenotype VII. 2 in wild birds in Turkey. BMC Veterinary Research, 16(1), 277. https://doi. org/10.1186/s12917-020-02503-3

Umali, D. V., Lopez, A. L. M., Torres, M. I. P., Umandal, M. C., \& Katoh, H., (2017). Molecular characterization and phylogenetic analysis of Newcastle disease virus isolated from clinical cases of Newcastle disease in commercial layer farms in the Philippines. Philippines Journal of Veterinary Medicine, 54(1), 17-26. https://doi. org/10.14943/jjvr.69.1.73

Vidanović, D., Šekler, M., Ašanin, R., Milić, N., Nišavić, J., Petrović, T., \& Savić, V. (2011). Characterization of velogenic Newcastle disease viruses isolated from dead wild birds in Serbia during 2007. Journal of Wildlife Diseases, 47(2), 433-441. https://doi.org/10.7589/0090-355847.2 .433

Wajid, A., Dimitrov, K. M., Wasim, M., Rehmani, S. F., Basharat, A., Bibi, T., Arif, S., Yaqub, T., Tayyab, M., Ababneh, M., Sharma, P \&
Afonso, C. L. (2017). Repeated isolation of virulent Newcastle disease viruses in poultry and captive non-poultry avian species in Pakistan from 2011 to 2016. Preventive Veterinary Medicine, 142, 1-6. https://doi.org/10.1016/j. prevetmed.2017.04.010

Wajid, A., Dundon, W. G., Hussain, T., \& Babar, M. E. (2018). Pathotyping and genetic characterization of avian avulavirus-1 from domestic and wild waterfowl, geese and black swans in Pakistan, 2014 to 2017. Archives of Virology, 163(9), 2513-2518. https://doi.org/10.1007/s00705018-3902-y

World Organisation for Animal Health. (2012). Newcastle disease (infection with Newcastle disease virus). https://www.oie.int/fileadmin/ Home/eng/Health_standards/tahm/3.03.14_ NEWCASTLE_DIS.pdf

World Organisation for Animal Health. (2018). Principles of veterinary vaccine production. https://www.oie.int/fileadmin/Home/eng/ Health_standards/tahm/1.01.08_VACCINE_ PRODUCTION.pdf

Xiao, S., Paldurai, A., Nayak, B., Samuel, A., Bharoto, E. E., Prajitno, T. Y., Collins, P. L., \& Samal, S. K. (2012). Complete genome sequences of Newcastle disease virus strains circulating in chicken populations of Indonesia. Journal of Virology, 86(10), 5969-5970. https://doi. org/10.1128/JVI.00546-12

Xie, Z., Xie, L., Chen, A., Liu, J., Pang, Y., Deng, X., Xie, Z., \& Fan, Q. (2012). Complete genome sequence analysis of a Newcastle disease virus isolated from a wild egret. Journal of Virology, 86(24), 13854 -13855. https://doi.org/10.1128/ JVI.02669-12

Zhang, R., Wang, X., Su, J., Zhao, J., \& Zhang, G. (2010). Isolation and analysis of two naturally occurring multi-recombination Newcastle disease viruses in China. Virus Research, 151(1), 45-53. https://doi.org/10.1016/j.virusres.2010.03.015 